2018

\title{
SPECIAL ISSUE - CALL FOR PAPERS: Applications of Judgment and Decision Making to Problems in Personnel Assessment
}

Edgar E. Kausel

P. Universidad Católica de Chile

Alexander T. Jackson

Middle Tennessee State University

Follow this and additional works at: https://scholarworks.bgsu.edu/pad

Part of the Human Resources Management Commons, Industrial and Organizational Psychology Commons, and the Other Psychology Commons

How does access to this work benefit you? Let us know!

\section{Recommended Citation}

Kausel, Edgar E. and Jackson, Alexander T. (2018) "SPECIAL ISSUE - CALL FOR PAPERS: Applications of Judgment and Decision Making to Problems in Personnel Assessment," Personnel Assessment and Decisions: Number 4 : Iss. 1 , Article 5. DOI: https://doi.org/10.25035/pad.2018.005

Available at: https://scholarworks.bgsu.edu/pad/vol4/iss1/5

This Main Article is brought to you for free and open access by the Journals at ScholarWorks@BGSU. It has been accepted for inclusion in Personnel Assessment and Decisions by an authorized editor of ScholarWorks@BGSU. 


\title{
SPECIAL ISSUE: CALL FOR PAPERS
}

\section{Applications of Judgment and Decision Making to Problems in Personnel Assessment}

\section{Guest Editors:}

\author{
Edgar E. Kausel \\ School of Management \\ Pontificia Universidad Católica de Chile \\ ekausel@uc.cl
}

\author{
Alexander T. Jackson \\ Department of Psychology \\ Middle Tennessee State University \\ alexander.jackson@mtsu.edu
}

\begin{abstract}
AIM AND SCOPE
Personnel judgments and decisions are ubiquitous in organizational life. For example, virtually all employee hiring scenarios come down to decisions about job candidates, such as the decision to invite the applicant for an interview or to make an employment offer. Likewise, most performance appraisal systems rely heavily on judgments (i.e., job performance ratings). As such, ways to improve managerial judgment and choice is an important issue in industrial-organizational psychology research and practice.

Judgment and decision making (JDM) research examines how people make decisions, which biases are common and consequential in decision making (i.e., the descriptive approach), and what can be done to improve decision making competence (i.e., the prescriptive approach). Consider a study conducted by Bohnet and her colleagues (2015). Gender bias is widespread in the assessment of job candidates in business, government, and academia. Given this, Bohnet presented an intervention in which candidates are evaluated jointly as opposed to separately regarding their future performance. The authors found that joint evaluation increased the use of relevant predictors of job performance, while separate evaluation increased the use of group stereotypes. This is a nice example of how an experimental study, based on previous descriptive research, presented a prescriptive solution to an important problem.
\end{abstract}

This special issue seeks papers based on laboratory, online, and field experiments as well as survey, archival, and qualitative data examining personnel judgment and decisions using JDM theories and research as their guiding framework-either from descriptive, prescriptive, or both approaches. In addition, authors may submit theory development papers. Examples of research questions that might be addressed include:

- Research on how people make personnel selection decisions or performance evaluation judgments using descriptive models.

- Potential interventions to increase decision making competence among managers and recruiters.

- Predictors and individual differences in decision making skill, style, and competence.

- Heuristics and biases that are relevant for personnel judgments and decisions as well as ways to overcome these heuristics and biases.

- Relatively unexplored decision-making constructs that are relevant for decision making competence, such as indecisiveness.

- How critical thinking or cognitive reflection may improve managerial decision making.

- Potential tradeoffs between decision making competence and adaptiveness.

- Resistance and reactions to both evidence-based hiring decisions and alternative hiring systems.

- Candidates reactions to various personnel assessment processes and systems, especially alternative systems.

- Overcoming barriers to evidence-based decision making in personnel assessment.

- Replication of classic or seminal JDM findings applied to personnel assessment contexts.

Note that these are merely examples of research topics, and we welcome the submission of any manuscripts that advance our understanding of JDM principles in a personnel assessment and decision contexts.

Please indicate in your cover letter that you are submitting your manuscript for the special issue. 